日消外会哂

特集 5

$$
\text { 大腸ポリープと癌 }
$$

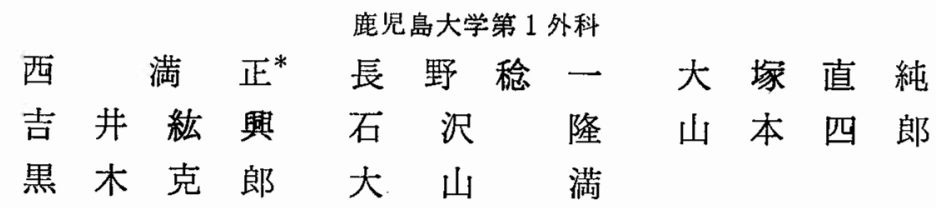

$$
\begin{gathered}
\multicolumn{3}{c}{\text { 鹿児島大学第 } 1 \text { 病理 }} \\
\text { 渡辺研之 }
\end{gathered}
$$

\title{
POLYP AND GANGER OF LARGE BOWEL
}

\section{NISHI*, T. NAGANO*, N. OTSUKA*, H. YOSHII*, T. ISHIZAWA*, S. YAMAMOTO*, K. KUROKI*, M. OYAMA* and K. WATANABE**}

*The First Department of Surgery (Director: Prof. M. NISHI, M.D.) Faculty of Medicine, Kagoshima University

**The First Department of Pathology (Director: Prof. H. IZAKA, M.D.) Faculty of Medicine, Kagoshima University

大腸にはポリープが多い，しかも癌との区別が困難なもの，多発するものが多い，これらの処置につい ては外科医がしぱしば悩まされている。

大腸のポリープと癌には疫学や腫㳻発生学の面からも興味のつきない点が多くある. 今回われわれは入 院手術症例, 直晹鏡集検例, 大腸ポリポージス症例, ソテッ毒による大晹発癌実験例などについて検討し た。

私はポリープの癌化率をらんぬんする前に，ポリープの種類をよく知ること，癌の判定基準を明らかに すること，何よりるポリープを慎重に取り扱うことを強調したい。

はじめに

最近ポリープの癌化率がしばしば問題にされる。そし て胃のポリープは癌化しないが, 大腸のポリープは癌化 するとよく云われる。この場合にポリープや癌化の定 義，癌と非癌の判定基準などを可能なかぎり明確にする 必要がある。

われわれは今回次の頂目に分けて述べる

1）教室に括ける大腸癌, 癌とポリープの併存例, 及 びポリープなどの入院手術症例.

2）大腸の内視鏡集検 973 例中発見されたポリープ87 例 106 個, 及び癌 6 例.

3）ポリポージス 5 例の詳細な肉眼的及び組織学的検

$$
\text { * 教授 }
$$

討による癌との関係.

4）ラットに対するサイカシン投与（第I群経口 30 匹, 第 II 群注腸33匹, 第 II 群外結腸㾇造設後注腸 $31 匹$ ) 発癌実験にみられた腸隆起性病变（170個）の検討. 以上の 4 点である.

\section{I 入院手術例について}

昭和38年より 49 年 6 月までの約 10 年間の大腸肛聞疾患 外来患者は1820名であり，外来患者総数 25,776 名の $7 \%$ にあたる. 入院した 235例中, 良性79例, 悪性 156例で ある。

(i) 単発の良性隆起性病変は 9 例あり, fibroepithelial polyp, 潰場辺縁のpseudo polyp, papillaly adenoma, 粘膜内糞石, juvenile polyp, proctitis を伴つた pseudo 
polyp 各 1 例の活か Adenomatous polyp 3 例であり, 血 便を主訴として外来では癌を疑われて入院, 手術 (polypectomy 6 , partial resection 2 , hemicolectomy 1 ) されたるのである。

(ii) ポリポージスを除く大腸肚門癌の polyp 併存は 156例中22例にみられたが，昭和48年以降では35例中10 例でありそれ以前の 121 例中12例より高頻度となつて打 り手術標本の丁寧な観察が必要である（表 1 ）.ポリープ 併存癌は直腸 $\left({ }^{11} / 81\right) \mathrm{S}$ 結腸 $(5 / 32)$ に多い。市た肉眼癌 型別にポリープ併存率をみるとBorrmann I 型29\%( $7 / 24)$ II 型 $17 \%\left({ }^{12} / 69\right)$ III型 $8 \%\left({ }^{3} / 37\right)$ IV 型 0\% ( $\left./ 2\right)$ で全症 例の併存率 $15 \%\left({ }^{22} / 142\right)$ に比し Borrmann I 型癌のポリ ープ併存率は高い.

表 1 大腸 - 肛阴癌の部位的頻度及 Polyp 併存例

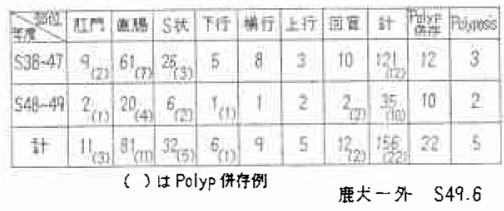

併存ポリープの数は，1ケ12例，2ケ 3 例，3ケ 4 例， 4 ケ 1 例， 5 ケ以上 2 例である.

(iii) 最近経験した下行結腸の拇指頭大有茥性の乳頭 状腺腫性ポリープ癌の一例は大部分が良性腺腫であるが 一部に境界領域病変と 2 ケの独立した癌巣があり 1 ケの 癌栄は大腸の正常粘膜に接したポリープ茥部にあつた。

近年大腸の早期癌に関する研究が進歩し, polypectomy を含めて小さな手術が施行される傾向があるが, 境界領 域や深達度の判定には十分な組織切片と正確な判断能力 が必要であり，安易に polypectomy を行つてはならな いと思う。

\section{II 集検発見例について}

関連病院の人間ドック入院患者に対し，直腸鏡の集検 をおこなつた結果 973例中87例に 106個の隆起性病変を 発見し生検した．過半数が 40 才〜 59才で膨大部にあり米 粒大〜小豆大の adenomatous あるいは hyperplastic の polyp であつた. 境界領域 1 例, 腺癌 6 例（そのうちカ ルチノイド2例）もあつた。（図1）

これら 6 例は小豆大〜示指頭大の小さなるので表 2 の 如く 5 例は無茥性であつた。

polyp も癌も左壁 ( 3 時方向) Kやや多からた。 小さ な polyp の生検には十分な polypectomy と,ていねい な固定, 多数の切片作成, 熟練した病理学者の判定, 責
図 1 集検発見の Polypoid 癌

\begin{tabular}{|c|c|c|c|c|c|c|c|c|}
\hline 企例 & 年令 & 性別 & 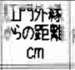 & polyonts: & 莰 & polypo性状 & 表面の性状 & 病理䧐断 \\
\hline 木 0 & 43 & $\delta$ & 8 & 示指頍 $\mathrm{A}$ & 無 & 的陷比 & $\begin{array}{l}\text { 発赤(一) } \\
\text { 丧面平滑 }\end{array}$ & 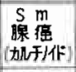 \\
\hline 10 & 48 & $\delta$ & 18 & 小指頭大 & - & 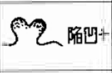 & 発赤 $(+)$ & $\begin{array}{c}m \\
\text { 腺癌 } \\
\text { (高节化) }\end{array}$ \\
\hline 瀬 ○ & 70 & 우 & 5 & 小豆大 & " & S & $\begin{array}{l}\text { 発赤(十) } \\
\text { 也」黄色 } \\
\text { 平滑 }\end{array}$ & 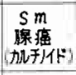 \\
\hline 守 0 & 49 & $\hat{\delta}$ & 9 & 大豆大 & 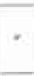 & & $\begin{array}{l}\text { 発赤(t) } \\
\text { 顆粒状 }\end{array}$ & 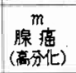 \\
\hline 上O瀬 & 51 & sิ & 11 & 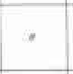 & * & & $\begin{array}{l}\text { 発赤(一) } \\
\text { 平滑 }\end{array}$ & 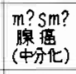 \\
\hline 須 ○ & 62 & 숭 & 12 & 小㰯大 & 有 & 3 & villous樣 & 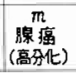 \\
\hline
\end{tabular}

任のある follow upなどが必要なことは当然である.

正確な記載を欠く不十分な polypectomy や，いい加減 な組織検査はむしろ有害であるといつてよい。

\section{III 大腸ポリポージスについて}

教室に括けるビマン性大腸ポリープ症は10例である. このらち大腸ポリポージス 7 例, Peutz-Jeghers症候群 3 例である。

Peutz-Jeghers症候群 3 例の確認されたポリープはそれ ぞれ 4 個，6 個，2 個であり，このうち摘出したポり一 プは症例 8 の 4 個, 症例 9 の 5 個である. 悪性所見は認 めなかつた。

1)大腸ポリポージス 7 例について

年令は19才より67才まで広範围にわたつて分布し，年 令に特徵を見いだせない。男女比は $3 ： 4$ で特に性差を 認めない.

肉眼的にみた進行癌との併存症例は，症例 $1 ， 2$, 6,7 で, 症例 1 は上行結腸に $3 \mathrm{~cm} \times 2 \mathrm{~cm}$, 症例 2 は S 字 結腸に $6 \mathrm{~cm} \times 7 \mathrm{~cm}$, 症例 6 は下行結腸に $2 \mathrm{~cm} \times 2 \mathrm{~cm}, \mathrm{~S}$ 字結腸に $5 \mathrm{~cm} \times 6 \mathrm{~cm}$, 症例 7 は盲腸に $8 \mathrm{~cm} \times 7 \mathrm{~cm}$, 直腸 に $4 \mathrm{~cm} \times 9 \mathrm{~cm}$ 癌をそれぞれ認めた。切除標本のポリー プ数（再手術症例では初回手術時のもの）は症例 7 では 蹯な分布を示すが，残りの6 症例は 2,150 個より 5,401 個迄であつた。

\section{2）ポリープ癌について}

（i）異型度分類. 大腸ポリポージスのポリープを異 型度により 3 群に分類した．I群．正常ないし軽い異型 増殖群. II 群. 境界領域群癌か疑われるが確証のないも の. 芣群. 明らかな癌である.今回われわれが癌とした のは，(1) 明らかな back to back を認めるもの，(2) 基底膜を破つてはいないが増殖せる異型度の強い細胞群 
図 2 教室に於ける大腸ポリポージス 1

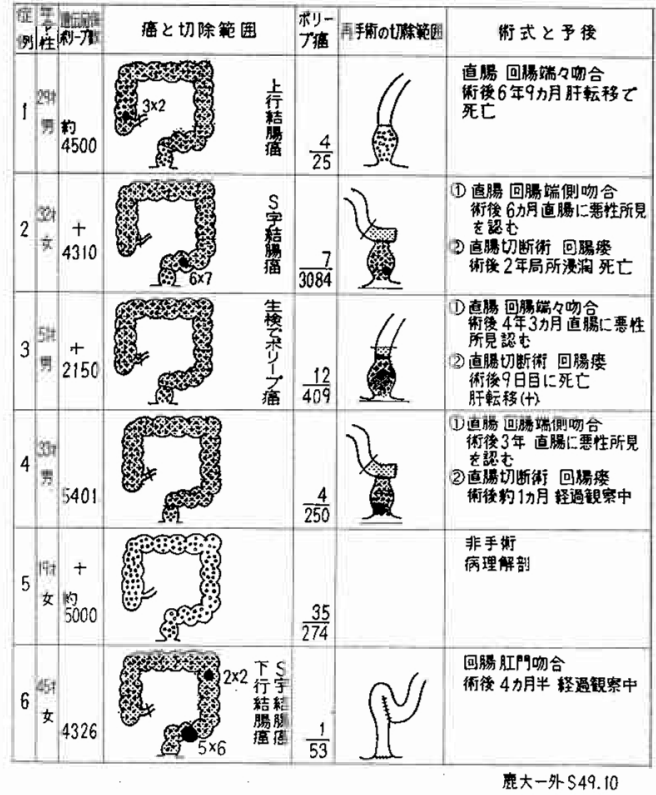

が正常細胞をはね上げている像，(3) 浸潤像を呈するも のである.この考えで以前われわれが癌としたポリープ を再検討した結果, 一部のポリープはII 群に再分類され た.

上記の分類でポリープ癌とされたポリープは図 2 に記 載してある．症例 7 は約 300 個のポリープのある症例で あるが目下検討中のため除外した，肉眼的に進行癌を認 めない症例 3，4，5に䋆いてポリープ癌が認められるこ とは大腸ポリポージスのポリープが肉眼的に明らかな癌 でなくても組織学的に悪性であるるのが多い.

(ii) 長径別, 各症例の異型度の比率 (表 2) 癌恰 索せるポリープ4095個中63個（1.5\%）でその頻度は少 ないしかし10 m以上では106個中47個(43.9\%)と高い. 症例別にみると $4.9 \mathrm{~mm}$ 以下では，他の症例には認めな

表 2 各症例の癌の長径別による比率

\begin{tabular}{|c|c|c|c|c|c|c|c|c|}
\hline 長径 & 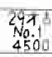 & $\begin{array}{l}327 \% \\
N 6.27 \\
4310\end{array}$ & 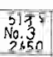 & $\begin{array}{l}333.8 \\
\text { No. } \\
5.01\end{array}$ & $\begin{array}{l}19799^{9} \\
\text { No.5 } \\
50000\end{array}$ & $\begin{array}{l}45,7 \\
\text { No. } \\
\text { 4. } \\
4326\end{array}$ & 計 & $\%$ \\
\hline$\sim 4 \begin{array}{l}4.9 \\
\mathrm{~mm}\end{array}$ & $\frac{0}{19}$ & $\frac{0}{2740}$ & $\frac{0}{138}$ & $\frac{0}{197}$ & $\frac{1}{180}$ & $\frac{0}{19}$ & $\frac{1}{3293}$ & 0.03 \\
\hline $5.0 \sim 9.9$ & $-\frac{1}{3}$ & $\frac{3}{336}$ & $\frac{2}{231}$ & $\frac{1}{48}$ & $\frac{8}{53}$ & $\frac{0}{25}$ & $\frac{15}{696}$ & 2.16 \\
\hline $10.0 \tilde{m}$ & $-\frac{3}{3}$ & $\frac{4}{8}$ & $\frac{10}{40}$ & $\frac{3}{5}$ & $\frac{26}{41}$ & $\frac{1}{9}$ & $\frac{47}{106}$ & 44.34 \\
\hline 竐 & $\frac{4}{25}$ & $\frac{7}{3084}$ & $\frac{12}{409}$ & $\frac{4}{250}$ & $\frac{35}{274}$ & $\frac{1}{53}$ & $\frac{63}{4095}$ & 1.54 \\
\hline$\%$ & 16.0 & 0.2 & 2.9 & 1.6 & 12.8 & 1.9 & & \\
\hline
\end{tabular}

いが症例 5 は 1 個のポリープ癌があり $5 \mathrm{~mm} \sim 9.9 \mathrm{~mm}$

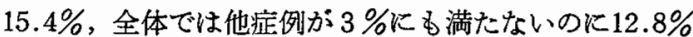
を示し，他症例と比較してポリープ癌が多く，とくに長 径の短いポリープ癌のあることが特徵である。

境界領域とした II 群も癌と同様に長径が長くなればな るほどその 比率は增加し, 症例 4 のように II 群と癌を 合わせると $10 \mathrm{~mm}$ 以上では 100\%を示す症例むあつた（図 3 ).

図 3 長径別各症例の異型度の比率

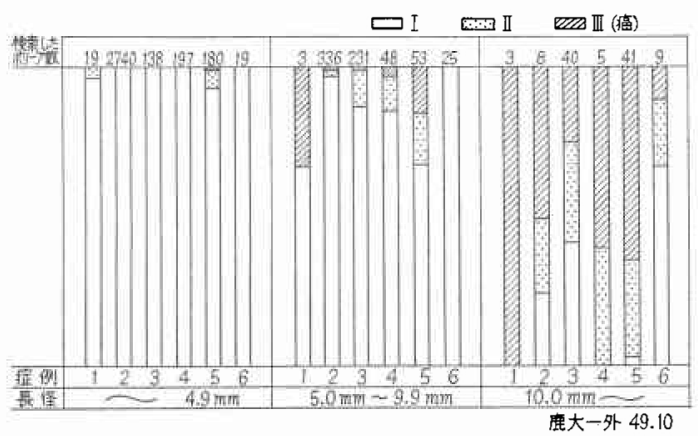

各症例とも長径が長くなれば異型度が強くなり10m以 上のポリープには充分注意する必要がある，尚ポリープ は組織学的には全部腺腫性ポリープであつた。症例 1 は 約 4500 個のポリープがみられる症例であるが，検索個数 が少ないので癌の比率が高くなつている。

\section{3）術式・予後}

大腸ポリポージス 7 例のうち, 剖検発見 1 例のほか, 結腸全摘出術直腸回腸吻合は 4 例，右半結腸切除十直腸 切断術 1 例，大腸全摘出回腸肛門吻合は 1 例である. 直 腸を残存した 4 例は術後 6 年 9 カ月肝転移死亡の症例 1 のほか術後 6 カ月， 4 年 3 カ月， 3 年でいずれも直腸癌 のため直腸切断術を施行されている。

上述したように大腸ポリポージスは, その遣伝歴の有 無にかかわらず癌化率が高いし，予後は不良であつた。

\section{IV 大腸発癌実験}

日本人の在米二世, 三世に胃癌が減少し, 大腸癌が増 加しているという現象は興味深い。

また大腸ポリープの癌化過程や大腸癌がどうして直腸 やS 状結腸に多いのかなどを知るために大腸の発癌実験 は大いに参考となる。

われわれは, ソテッ毒を径口, 注腸, 外結腸瘻浩設後 注腸の 3 群に分けて実験を行つた。

1) ソテッ毒について

奄美大島産ソテッ Cycas revoluta Thunb 種子に毒性 
成分の含まれていることは古くより知られており，西 田ら（1955）によつて単離および構造の決定がなされ Cycasin glucosyl-oxyazoxymethane<smiles>CCOON([O])C(C)=O</smiles>
と名付けられた。一方, Laqueur らはグアム島産ソテッ Cycas circinalis L に発癌性のあることを発見し，その 本態が Cycasin であることを報告した。（1963）渡辺 は Spraque-Dawley系 (以下 S-D) ラットを用いた実験で Cycasin の投与方法, 即ち投与量之投与期間を操作する ことにより, その発癌標的蔵器 (肝, 監, 腸管等) が限 定されることを報告した。（1970，1972）それによる 之腸管腫瘍の発生には中等量頻回投与即ち Cycasin 50 $\mathrm{mg} / \mathrm{kg}, 12$ 回投与が最適と考光られる.

\section{2）実験材料及び方法}

実験動物には生後50日の S-D 系ラット，両性を使用し た（動物は $22 \pm 5{ }^{\circ} \mathrm{CK}$ 保たれた動物室で飼育, 飼料はオ ルエンタル M F 固型飼料を制限なく投与）実駼期間を通 じて週 2 回体重測定を行い，体重減少や著しい重篤所見 を認めた場合は屠殺, 或いは自然死せるものの剖検によ り腫瘍を発見した。また発癌物質として使用したソテッ 抽出液はガスクロマトグラフィーで定量の結果 Cycasin $16.6 \mathrm{mg} / \mathrm{cc}$ であつた。実験群は次の 3 群に分けたが，い づれの群もCycasin $50 \mathrm{mg} / \mathrm{kg}$, 即ちンテッ抽出液 $3 \mathrm{cc} / \mathrm{kg}$ を週 1 回, 計12回与えた。

第 I 群 雌10匹, 雄20匹にソテッ抽出液を経口投与

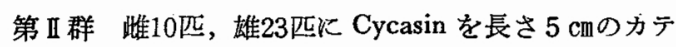
ーテルを用いて肛門より注晹.

第群 雌11匹，雄20匹に対し生後45日目に上行結腸 に外結腸媚造設, 術後 7 日目よりッテッ抽出液をカテー テルを用いて肍門上り注腸.

\section{3）実験結果}

(i) 腫瘍の発生頻度及 び 発生迄の日数（表 3 ） Cycasin 飞上る腸管腫湟の発生頻度は有効動物を 6 力月 表 3 ソテッ毒に上る腸管腫場の発生

\begin{tabular}{|c|c|c|c|c|c|c|}
\hline \multirow{2}{*}{$\begin{array}{l}\text { 蹇 } \\
\text { 群 }\end{array}$} & \multirow{2}{*}{ 性 } & \multirow{2}{*}{$\begin{array}{l}\text { 有 効 } \\
\text { 動物数 }\end{array}$} & \multicolumn{3}{|c|}{ 腸 管 䠑 㿋 } & \multirow{2}{*}{ ヒの他の腫琼 } \\
\hline & & & Hbotess & 垂䭪数 & 発生までの日致 & \\
\hline \multirow{2}{*}{ I } & 우 & 8 & 7 & 41 & $\begin{array}{l}340.2 \pm 20.4 \\
(306 \sim 362)\end{array}$ & 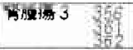 \\
\hline & $\hat{\jmath}$ & 16 & 16 & 71 & $\begin{array}{l}237.0 \pm 36.8 \\
(171 \sim 322)\end{array}$ & - \\
\hline \multirow{2}{*}{ II } & q & 7 & 5 & 12 & $\begin{array}{l}355.1 \pm 120.7 \\
(179 \sim 534)\end{array}$ & 㥠脽流1 402 \\
\hline & t & 12 & 11 & 35 & $\begin{array}{l}445.1 \pm 120.4 \\
(149 \sim 534)\end{array}$ & - \\
\hline \multirow{2}{*}{ III } & ? & 6 & 3 & 4 & $\begin{array}{l}457,545 \\
545,457\end{array}$ & - \\
\hline & $\delta$ & 12 & 4 & 7 & $\begin{array}{c}405.8 \\
(310 \sim 545)\end{array}$ & - \\
\hline
\end{tabular}

以上生存したものとすると, I 群では雙 $7 / 8(87.5 \%)$ に 41個, 雄16匹全例に71個, II 群では雌 $5 / 7(71.4 \%)$ に12 個, 雄 $\left.{ }^{11} / 12 （ 91.7 \%\right)$ に35個，群では雌 $3 \%$ （50\%）に 4 個, 雄 ${ }^{4} / 12(33.3 \%)$ に 7 個で一般に雄性飞頻度が高 い. 発生までの日数は最も短いものは149日で, 両性共 に I 群>II 群> II 群の順に発生頻度は高く, また発生ま での日数も短い。とくに四群における頻度の著明な低下 及び発生までの期間の途延は外腸瘦形成後の肛門側を 内容が通ら始ことにより，Cycasin の分解活性化飞必 要なる腸内紐菌の減少, 粘膜萎縮により活性化された Methylazoxymethanol（以下MAM）の吸収の低下によ ると考えられる。

（ii）腸管腫县 の発生部位は図 4 の如くI群におい ては十二指腸より直腸に至る全腸管に文られ，結腸中央 部に最も多い，II群では全て結腸に発生しており, とく に肛門側に圧倒的に多く Cycasin の直接作用を思わせ る. III群では回腸の1個を除いては全て結腸にみられ たが, 外腸㾇より口側 6 , 肛門側 4 で, とくに雌性では 全て外晹瘦口に発生したもので口側 3 , 肛門側 1 であつ た. Cycasin の腸管腫場の発生機序に関し，(1) 投与さ れた Cycasin が腸内細菌によつてMAMK分解され，そ

図 4 腸管腫湟の分布

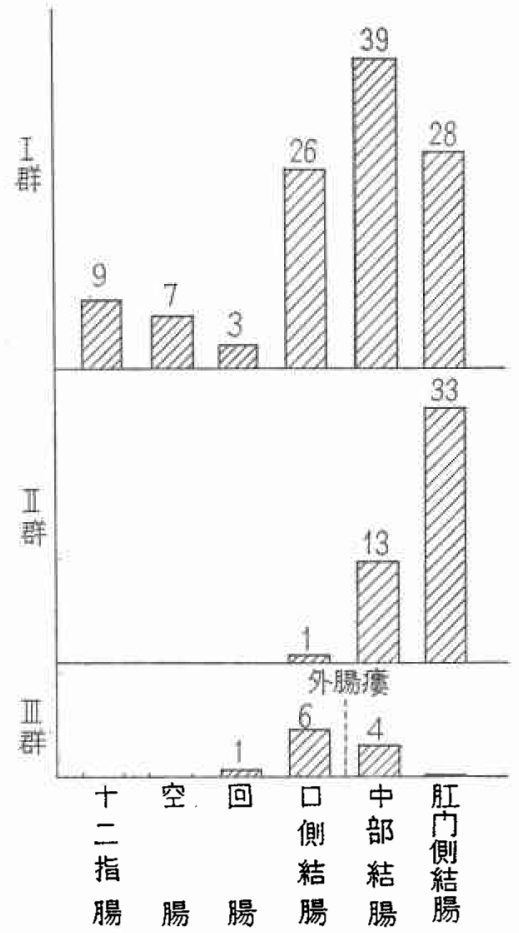


図 5 実験大腸腫晹の大ささと良悪性の関係

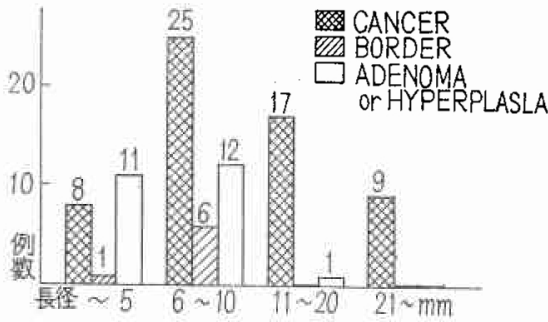

のMAMが直接腸管粘膜に作用する。（2) MAMまたは その代謝産物が胆汁中に分泌され，腸管に作用する．(3) MAMKより肝に機能的な障害が沶こり，胆汁成分に異 常を来たし，これが腸管腫瘍発生につながる，の三点が 考えられてきたが，(1)を主，(2)を従の発癌機構が証明さ れた。また腸管内容の流通すなわち，便通が腸管腫瘍発 生に影響することも充分考えられよう。

(iii) 大腸腫瘍の肉眼的観察. I ，II群において発生 した大腸腫瘍について検討を加えたが，大きさは 6 〜 10 mmあのがもつとも多い.

また腫場の肉眼的形態を有茥型 (polyp type)，亜有茥 型 (polypoid type), 半球型 (hemispheric type), 平盤隆 起型 (elevated type), 潰陽形成外側浸潤型 (ulcerated type）の 5つの型に分類すると有茎型が最も多い. 瘇痬 形態と発生部位との関係は潰瘍形成型が中央部結腸に多 い。

(iv) 組織学的検索. 組織学的には腫瘍は全て上皮性 で, 種々の異型を示す腺腫及び腺癌の像を示す．これら を(1)異型性の少い良性腺腫と思われるもの，(3)異型性が 強く明らかに腺癌とみられるもの，(2そ)中間にあるも のの三つに大別した．それによると 5 個の粘液結節性腺 癌, 或いは単純癌を含んで腺管腺癌69個 $(56.9 \%)$, 良性 腺腫42個（34.2\%）境界領域11個（8.9\%）であつた。 肉眼的形態との関係は有茎型は良性が多く, 腺䐑内への 增殖傾向が弱いもの程, 悪性の傾向が強まり, 潰瘍形成 外側浸潤型では全て覀性であつた。またI 群の大腸腫瘍 90例に括いて大きさとの関係は 5 四以下のものでも $8 / 20$ （40\%）が悪性で大きさを增すにつれ悪性化を增し，21 m以上では全例悪性であつた (図 5 ). 実験的大腸癌では 比較的転移をみることは少ないが I 群において 6 例の領 域リンパ節，1例の肺への転移を認めた。

転移巣はいずれる粘液産生細胞像を呈するが，原発腫 湯は 3 例において 4 個の粘液結節性腺癌がみられ 1 例は 単純癌, 2 例は腺管腺癌であつた。
以上ソテッ毒によるラッテに対する大腸発癌実験では かなり高率に癌がみられ（5 m以下でも40\%が癌）始め から癌として発生するものもあると思われる．また肝を 経由する間接作用のほかに直接的な大腸粘膜への発癌作 用も充分に考充られた。

\section{むすび}

大腸ポリープには異型上皮と癌との判定が困難なるの がある.今回われわれは, 明らかな良性病変と癌の中間 に, 癌が疑われるが確証のないgroup を境界領域病変と した。

入院手術症例, 内視鏡集検症例, ポリポージス症例, 動物実験の四項目にわけて検討した結果は次の通りであ る.

1. 最近10年間に入院した大腸ポリープ 9 例，ポリー プと癌の併存22例, 及び大腸癌 132例についてみると, ポリープ併存癌は Borrmann I 型が多く, 直腸及び $\mathrm{S}$ 状 結腸の癌に多かつた。

2. 大腸の内視鏡集検 973例中に発見されたポリープ 106個（87例）の大部分は過形成性あるいは腺腄珄ポリ ープであつた．腺癌は6 例（カルチノイド 2 例含む）で 5 例は無茎性であつた。

3. 教窒の多発性大腸ポリープ症10例のうち PeutzJeghers 症候群 3 例に癌はない. ポリポージス 7 例のうち 6 例のポリープ4095個について詳細な組織学的検査をお こなつた. 長径 $1 \mathrm{~cm}$ 以上では $44 \% に$ 癌化がみられている.

ビマン性ポリポージスの中には症例によつて癌化率の 高い症例がある．面腸を残存せしめた症例にはすべて直 腸癌が発生している。

4. Cycasin によるラット発癌実験 では，経口，注 腸, 外結腸瘦造設後注腸の 3 群とむかなり高率に大腸の polyp と癌がみられた。

以上大腸のポリープと癌との関係について入院手術症 例. 直腸鏡集検例，ポリポージス症例などを対象とした 臨床病理学的検討と, ラットに対するソテッ毒による大 腸発癌実験の結果を述べた。

臨床例，動物実験を通じて大腸のポリープは癌化しゃ すいかも知れないが，始めから癌 (de' neuvau) のもの ああると思われる，ポリープの癌化率に関しては大腸に は良性ポリープが多く，境界領域病変も少なくないの で, 分母のとり方, 組織学的判定規準に注意が必要であ る.

要旨にも述べたよらに大腸ポリープの癌化率をらんぬ んする前に, ポリープの種類を良く知ること, 癌の判定 
規準を明らかにすること，何よりすポリープとくにポリ ープ癌を診断治療の両面に扎いて慎重に取り扱らべきこ とを強調したい。

\section{文 嗝}

1) Nishida, K. Kobayashi, A. \& Nagahama, T.: Cycasin, a new toxic glycoside of Cycas revoluta Thunb. I. Isolation and structure of cycasin. Bull. Agr. Chem. Soc. Japan. 19: 7784, 1955.

2）佐藤入郎汪か：Cycasin の発癌機槽下関する研 究（第 1 報）一奄美大島産ソテッ Cycas revoluta 種子の発癌性にっいて. 医学のあゆみ, $65: 525-531,1968$.
3）渡辺研之: Cycasin に上る腫倵発生, 投与方法 に上る標的䑏器の変動とその病理学的研究. 鹿 大医誌, $22: 199,1970$.

4) 西 满正ほか：結晹外科の問題点, 結晹虞にっ いて。 外科診寮, $14: 644,1972$.

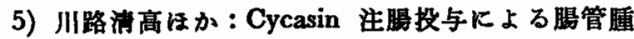
湯の発生について, 第32回日本癌学会総会記事. $186,1973$.

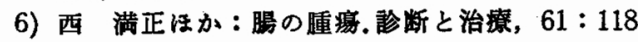
$-124,1973$.

7）柚木一雄泳か：サイカシンによる実験大渴癌, 医学のあゆみ, 88, 13，685一691，1974.

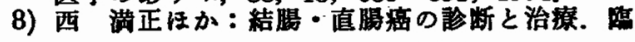
床と研究, $51 ： 1306-1312,1974$. 